Media, Persuasion and Propaganda 


\section{Media Topics}

Series editor: Valerie Alia

Titles in the series include:

Media Ethics and Social Change

by Valerie Alia

Media Policy and Globalization

by Paula Chakravartty and Katharine Sarikakis

Media Rights and Intellectual Property

by Richard Haynes

Alternative and Activist Media

by Mitzi Waltz

Media and Ethnic Minorities

by Valerie Alia and Simone Bull

Women, Feminism and Media

by Sue Thornham

Media Discourse

by Mary Talbot

Media Audiences

by Kristyn Gorton

Media and Popular Music

by Peter Mills

Media and Memory

by Joanne Garde-Hansen

Sex, Media and Technology

by Fiona Attwood

Media, Persuasion and Propaganda

by Marshall Soules

www.euppublishing.com/series/MTOP 


\title{
Media, Persuasion and Propaganda
}

\author{
Marshall Soules
}


(C) Marshall Soules, 2015

Edinburgh University Press Ltd

The Tun - Holyrood Road

12 (2f) Jackson's Entry

Edinburgh EH8 8PJ

www.euppublishing.com

Typeset in 10/12 Janson Text by

Servis Filmsetting Ltd, Stockport, Cheshire, and printed and bound in Great Britain by

CPI Group (UK) Ltd, Croydon, CR0 4YY

A CIP record for this book is available from the British Library

ISBN 9780748644162 (hardback)

ISBN 9780748644155 (paperback)

ISBN 9780748644179 (webready PDF)

ISBN 9780748696437 (epub)

The right of Marshall Soules

to be identified as author of this work

has been asserted in accordance with the

Copyright, Designs and Patents Act 1988

and the Copyright and Related Rights

Regulations 2003 (SI No. 2498). 